\title{
Adhesive systems used for sealing contaminated surfaces: a microleakage evaluation
}

\section{Estudo de microinfiltração sob sistemas adesivos usados como selante em superfícies contaminadas}

\author{
Rosa Helena Miranda Grande* \\ Alessandra Reis** \\ Alessandro Dourado Loguercio** \\ Julio da Motta Singer*** \\ Edward Shellard $* * * *$ \\ Paulo Christino Neto ${ }^{* * * * *}$
}

\begin{abstract}
The aim of this study was to compare two adhesive systems (OptiBond FL ${ }^{\mathrm{TM}}$ and OptiBond SOLO ${ }^{\mathrm{TM}}$ ) used as a sole material for sealing pit and fissures on contaminated surfaces with respect to microleakage. After acid etching, 56 sound teeth were contaminated with $1 \mu \mathrm{l}$ of plasma and randomly divided into 8 groups (n=7). The adhesives were light activated under two conditions (Optilux VCL-403 ${ }^{\mathrm{TM}}$ and VCL-500 ${ }^{\mathrm{TM}}$ ) for $30 \mathrm{~s}$. Each specimen was exposed to one of the following aging treatments: thermal $\left(4,000 \mathrm{X}\right.$ at $5-55^{\circ} \mathrm{C}$ for $\left.60 \mathrm{~s}\right)$ plus load cycling $(225,000 \mathrm{X}$ with $83.3 \mathrm{~N})$ or thermal plus load and $\mathrm{pH}$ cycling (mineralizing/demineralizing solutions). Then, they were immersed in a $50 \% \mathrm{AgNO}_{3}$ aqueous solution, sectioned twice and had dye penetration measured through digitized images. ANOVA methods were used to assess the main effects of the factors as well as their interactions. The results indicated a significant difference between the adhesive systems $(p<0.05)$, suggesting that OptiBond $\mathrm{FL}^{\mathrm{TM}}$ has a better performance with respect to microleakage and could be used as a sealing material in accidentally moist or contaminated surfaces.
\end{abstract}

DESCRIPTORS: Dentin-bonding agents; Dental enamel; Dental leakage; Pit and fissure sealants.

RESUMO: O propósito deste estudo foi comparar dois sistemas adesivos (OptiBond FL ${ }^{\mathrm{TM}}$ e OptiBond SOLO ${ }^{\mathrm{TM}}$ ) utilizados como material único para selar superficies oclusais contaminadas com relação à infiltração marginal. Após condicionamento ácido, 56 dentes hígidos foram contaminados com $1 \mu 1$ de plasma e aleatoriamente divididos em 8 grupos $(n=7)$. Os adesivos foram fotoativados por $30 \mathrm{~s}$ sob duas condições (Optilux VCL-403 ${ }^{\mathrm{TM}}$ e VCL-500 ${ }^{\mathrm{TM}}$ ). Cada espécime foi exposto a um de dois tratamentos de envelhecimento: ciclos térmicos $\left(4.000 \mathrm{X}\right.$ a $5-55^{\circ} \mathrm{C}$ por 60 s) mais ciclos mecânicos (225.000 X com carga de 83,3 N); ou ciclos térmicos, mecânicos e de pH (soluções mineralizante/desmineralizante). Os espécimes foram imersos em solução aquosa de $\mathrm{AgNO}_{3}$ a $50 \%$, secionados, e a penetração do corante foi medida em imagem digitalizada. Usou-se ANOVA para determinar os principais efeitos dos fatores e suas interações. Os resultados indicaram diferença significante entre os adesivos $(\mathrm{p}<0,05)$, sugerindo que o OptiBond FL ${ }^{\mathrm{TM}}$ apresenta um desempenho melhor com relação à microinfiltração e poderia ser indicado como material único para selamento em condições de umidade ou contaminação acidental.

DESCRITORES: Adesivos dentinários; Esmalte dentário; Infiltração dentária; Selantes de fossas e fissuras.

\section{INTRODUCTION}

The high susceptibility of pit and fissure sites to dental caries has received considerable attention since the $19^{\text {th }}$ century. In 1967, Cueto, Buonocore ${ }^{3}$ introduced a sealing technique which consisted of applying resinous material to these surfaces. Since then, this method has been established as an effective preventive tool against caries development ${ }^{25}$. According to Waggoner, Siegal ${ }^{25}$ (1996), the risk of caries is the first and main reason for sealing teeth. Dennison et al. ${ }^{5}$ (1990) suggested that

\footnotetext{
*Associate Professor, Department of Dental Materials, School of Dentistry; *** Professor, Department of Statistics, Institute of Mathematics and Statistics - University of São Paulo.

**Assistant Professors, Department of Dental Materials and Operative Dentistry, School of Dentistry, University of Western Santa Catarina.

$* * * *$ Researcher, Kerr Corporation, United States of America.

$* * * * *$ Assistant Professor, Department of Pediatrics, School of Dentistry, University of Northern Paraná.
} 
Grande RHM, Reis A, Loguercio AD, Singer JM, Shellard E, Christino Neto P. Adhesive systems used for sealing contaminated surfaces: a microleakage evaluation. Braz Oral Res 2005;19(1):17-22.

the eruptive stage of teeth must be considered carefully before sealing procedures, because the efficacy of adhesive techniques could be jeopardized by surface contamination. In this context, microleakage and partial/total loss of sealants due to salivary contamination are still the focus of concern $^{13}$.

Sealing erupting teeth is sometimes necessary and in such circumstances, maintenance of an adequate moisture control may be impossible. To minimize the deleterious effects of contaminated enamel on bonding, some authors have advocated the use of adhesive systems under the sealant. Such a combination has been analyzed in some in vitro studies ${ }^{6,13}$.

Alternatively, other authors have analyzed the use of filled adhesive systems for pit and fissure sealing ${ }^{11,26}$. These authors observed that OptiBond dual cure is less related to microleakage when applied either to contaminated or dry enamel surfaces. This feature of OptiBond was also apparent when specimens were subjected to thermal and/or load cycling, although these treatments increased microleakage in general ${ }^{26}$. The effectiveness of this alternative technique for sealing teeth under dry conditions was also demonstrated in a clinical trial where a higher retention rate for OptiBond dual cure in comparison with the use of Delton (a hydrophobic sealant) was detected ${ }^{12}$.

Besides dental material composition, other factors that may affect microleakage or adhesive failure are the photoactivation conditions and the change of environmental $\mathrm{pH}$ (demineralization/ remineralization cycles $)^{7,19}$. However, few attempts have been made to evaluate the effects of these factors on the sealing procedures.

Whereas clinical trials constitute the best way to provide information about the performance of dental materials, they are expensive and time-consuming. Furthermore, it is likely that the products under investigation might be outdated by the time the study is published. Microleakage analysis often relies upon predictors of clinical performance for adhesive-restorative approaches and materials ${ }^{10}$. It usually includes thermal and load cycling to simulate the oral environment and also to stress the adhesive interface ${ }^{1,10}$.

The objective of this study was to evaluate the performance of two adhesive systems, applied only to contaminated pit and fissure surfaces, activated under two conditions and subjected to two aging treatments (thermal and load cycling associated or not with $\mathrm{pH}$ cycling), with respect to microleakage.

\section{MATERIALS AND METHODS}

Fifty-six caries-free extracted human molars and premolars were cleaned and stored in a 0.4\% sodium azide solution (Sigma Co., St. Louis, USA) at $7^{\circ} \mathrm{C}$. They were embedded in acrylic resin (Clássico, São Paulo, Brazil) and randomly assigned to one of 8 groups $(\mathrm{n}=7$ ) defined by the combination of adhesive system (OptiBond $\mathrm{FL}^{\mathrm{TM}}$ or $\mathrm{SOLO}^{\mathrm{TM}}$ ), light activation (Optilux VCL-403 or Optilux VCL500 ) and aging treatment (thermal and load cycling $[\mathrm{T}+\mathrm{C}]$ or thermal, load and $\mathrm{pH}$ cycling $[\mathrm{T}+\mathrm{C}+\mathrm{pH}])$. The study was approved by the Ethics Committee of the School of Dentistry, University of São Paulo (FOUSP) (13/99).

All teeth were pumiced (SS White Ltda., Rio de Janeiro, Brazil) and rinsed thoroughly. Pit and fissure surfaces were then etched and contaminated with 1 microliter of human plasma followed by the application of the adhesive systems as depicted in Table 1 . The activation devices Optilux ${ }^{\mathrm{TM}}$ (Dem-

TABLE 1 - Composition and application mode of the adhesive systems.

\begin{tabular}{|c|c|c|}
\hline Adhesive system & Composition & Bonding procedure \\
\hline $\begin{array}{l}\text { OptiBond FL } \\
\text { Kerr; Orange, } \\
\text { CA, USA }\end{array}$ & $\begin{array}{l}\text { 1. Etchant: } 37.5 \% \text { phosphoric acid } \\
\text { 2. Primer: HEMA, GPDM, MMEP, ethanol, water, initiators } \\
\text { 3. Bonding agent: Bis-GMA, HEMA, GPDM, barium-aluminum bo- } \\
\text { rosilicate glass, disodium hexafluorosilicate, fumed silica }(48 \% \\
\text { filler) }\end{array}$ & $\mathrm{a}, \mathrm{b}, \mathrm{c}, \mathrm{d}, \mathrm{e}, \mathrm{f}, \mathrm{g}$ \\
\hline $\begin{array}{l}\text { OptiBond SOLO } \\
\text { Kerr; Orange, } \\
\text { CA, USA }\end{array}$ & $\begin{array}{l}\text { 1. Etchant: } 37.5 \% \text { phosphoric acid } \\
\text { 2. Bonding agent: Bis-GMA, HEMA, GPDM, ethanol, barium-alumi- } \\
\text { num borosilicate glass, disodium hexafluorosilicate, fumed silica } \\
\text { ( } 24 \% \text { filler) }\end{array}$ & $\mathrm{a}, \mathrm{b}, \mathrm{c}, \mathrm{d}, \mathrm{h}, \mathrm{g}$ \\
\hline
\end{tabular}

a - etching (15 s); b - rinse with distilled water (20 s); c - air-dry (15 s); d - contamination with $1 \mu$ l of human plasma (30 s); e - primer application (30 s); $\mathrm{f}$ - bonding agent; g - light activation (30 s); h - primer and bonding application. 
Grande RHM, Reis A, Loguercio AD, Singer JM, Shellard E, Christino Neto P. Adhesive systems used for sealing contaminated surfaces: a microleakage evaluation. Braz Oral Res 2005;19(1):17-22.

etron Res. Corp., Danbury, CT, USA) have the following characteristics: VCL 403 with $360 \mathrm{~mW} / \mathrm{cm}^{2}$ and VCL 500 with $590 \mathrm{~mW} / \mathrm{cm}^{2}$.

The specimens were subjected to thermal cycling $\left(4,000\right.$ cycles at 5 and $55^{\circ} \mathrm{C}$ with a dwell time of 60 seconds at each temperature) and to load cycling $(225,000$ times under $83.3 \mathrm{~N})$. During the load cycles, half of the sample was kept in distilled water, whereas the other half was immersed in demineralizing (180 $\mathrm{min}$ at $\mathrm{pH}=4.7)$ and mineralizing (30 $\mathrm{min}$ at $\mathrm{pH}=7.0$ ) solutions, alternately. The solutions were prepared similarly to those described by ten Cate, Duijsters ${ }^{23}$ (1982). Before being immersed in each solution, the specimens were rinsed with distilled water.

The dental crowns (except the sealed region and $1 \mathrm{~mm}$ around it) were coated with two layers of nail varnish (L'Oréal Inc., New York, USA), immersed in a $50 \%(\mathrm{w} / \mathrm{v})$ silver nitrate (Cennabras Ltda., Guarulhos, Brazil) aqueous solution ${ }^{27}$ $(\mathrm{pH} \sim 7.0)$ and kept in darkness for 2 hours $^{20}$. They were then washed, immersed in a photo-developing solution (Kodak, São José dos Campos, Brazil) and exposed to a fluorescent light (Osram, Buenos Aires, Argentina) for 8 hours ${ }^{20}$.

Each specimen was sectioned twice with a microtome (Labcut 1010, Extec Co., Enfield, CT, USA), under water-cooling, in a buccal-to-lingual direction in order to obtain 224 cross-sections that were digitalized (ScanJet 4c, HP, Palo Alto, CA, USA) to generate TIFF 600 dpi images. On each cross-sectional image, the whole linear interface between the adhesive and the enamel, as well as the extent of the dye penetration along this interface, were measured $(\mathrm{mm})$ at each cuspal incline with IMAGELAB (image analysis software developed at FOUSP, Brazil), generating a total of 448 observations ${ }^{26}$. For each tooth, the dye penetration was expressed as an average percentage of the length of the interfaces. Analysis of Variance (ANOVA) techniques were employed to evaluate the effect of adhesive systems, light activation and cycling as well as of their interactions ${ }^{17}$.

\section{RESULTS}

The average percentages of dye penetration (microleakage) along with the corresponding standard deviations for each group are shown in Table 2 .

ANOVA results indicate a significant $(p<0.001)$ Adhesive main effect as well as a significant $(p=0.012)$ Adhesive versus Light activation versus Cycling interaction. An analysis of the data in Table 2 and the plots in Graph 1 suggests that such an interaction may be classified as non-essential ${ }^{17}$ in the sense that OptiBond SOLO showed higher average percentages of dye penetration than OptiBond FL, irrespectively of the combination of the two other factors.

Although the average differences between the percentages of dye penetration related to the two adhesives is not uniform, we may conclude that on the average (across the combinations of the levels of light intensity and cycling), the mean percentage of dye penetration for the specimens treated with OptiBond FL is significantly lower $(p<0.001)$ than the corresponding percentage for OptiBond SOLO, as shown in Table 3.

\section{DISCUSSION}

Clinical preventive procedures, including sealing, are only conducted after a careful dental caries risk assessment. For posterior teeth, an intrinsic risk factor is the occlusal morphology. If extrinsic risk factors (e.g. eruptive stage, orthodontic appliance and caries lesions) are also considered, such teeth are potential candidates for sealing. In this process, however, a high risk of contamination is frequently involved. In such cases, alternative sealing techniques which minimize sealant failure under such conditions should be considered.

Previous studies ${ }^{11,26}$ have demonstrated that, when compared to conventional sealants or other adhesive systems, OptiBond dual cure used as sealant is related to less microleakage either in dry or contaminated surfaces. According to Duangthip, Lussi $^{6}$ (2003), the OptiBond system used alone or

TABLE 2 - Observed average percentages of microleakage \pm standard deviations.

\begin{tabular}{l|c|c|c|c}
\hline \hline \multirow{2}{*}{ Adhesives } & \multicolumn{2}{|c|}{$\begin{array}{c}\text { Light activation } \\
\left.\text { (VCL } 403-360 \mathrm{~mW} / \mathrm{cm}^{2}\right)\end{array}$} & \multicolumn{2}{c}{$\begin{array}{c}\text { Light activation } \\
\text { (VCL 500 }-590 \mathrm{~mW} / \mathrm{cm}^{2} \text { ) }\end{array}$} \\
\cline { 2 - 5 } & $\begin{array}{c}\text { Thermal and load } \\
\text { cycling }\end{array}$ & $\begin{array}{c}\text { Thermal, load and } \\
\mathrm{pH} \text { cycling }\end{array}$ & $\begin{array}{c}\text { Thermal and load } \\
\text { cycling }\end{array}$ & $\begin{array}{c}\text { Thermal, load and } \\
\mathrm{pH} \text { cycling }\end{array}$ \\
\hline OptiBond FL & $37 \pm 18$ & $47 \pm 24$ & $57 \pm 21$ & $42 \pm 20$ \\
\hline OptiBond SOLO & $88 \pm 17$ & $68 \pm 22$ & $84 \pm 14$ & $96 \pm 08$ \\
\hline \hline
\end{tabular}


Grande RHM, Reis A, Loguercio AD, Singer JM, Shellard E, Christino Neto P. Adhesive systems used for sealing contaminated surfaces: a microleakage evaluation. Braz Oral Res 2005;19(1):17-22.

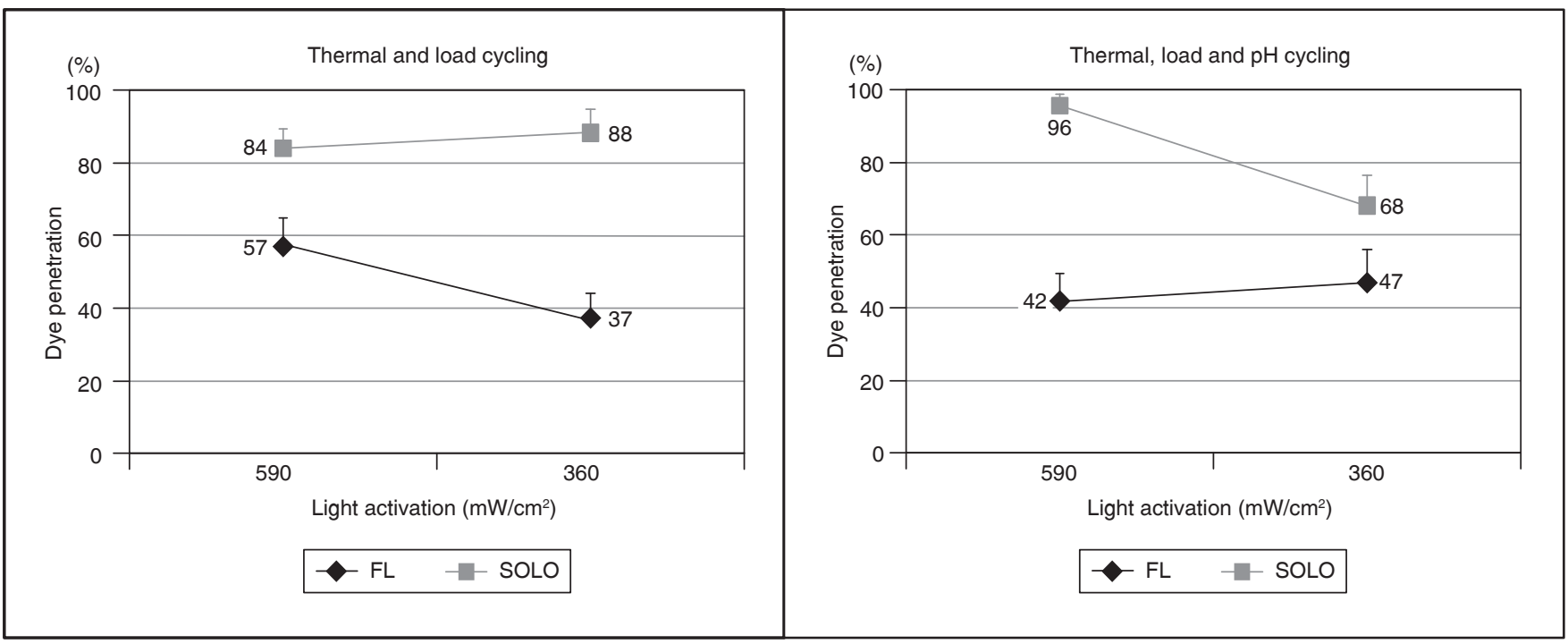

GRAPH 1 - Average microleakage profile plots.

TABLE 3 - Average estimated percentage of microleakage \pm standard errors.

\begin{tabular}{l|c}
\hline \hline \multicolumn{1}{c|}{ Adhesives } & Average \pm standard error \\
\hline OptiBond FL & $46 \pm 4$ \\
\hline OptiBond SOLO & $84 \pm 4$ \\
\hline \hline
\end{tabular}

associated with Concise showed reduced microleakage levels in wet saliva-contaminated surfaces. Jain, Stewart ${ }^{14}$ (2000) investigated the OptiBond system regarding bond strength to dry and moist enamel and found no significant differences. Its reduced sensitivity to humidity, higher filler content, viscoelastic properties, primer ability to displace and/or tolerate some degree of moisture and its high diffusion coefficient (which allows penetration into interprismatic spaces as well as etched enamel rod ends) are factors that may contribute to such a performance $e^{6,11,12,22}$.

Both adhesive systems tested in this study have similar monomer composition, but OptiBond FL showed a better performance with respect to the percentage of dye penetration ( $\mathrm{p}<0.001)$. OptiBond FL has a separate priming step (a solution that contains low molecular weight monomers and solvents like ethanol and water) that is applied beforehand and thus may facilitate the permeation of the monomers into the contaminated etched enamel. OptiBond SOLO has half the filler content of OptiBond FL; however, there are highly viscous solutes in the solvent of the former that could make the spreading difficult.
Other attempts have been made towards achievement of better marginal sealing results in bonding procedures. The use of polymerization techniques that initially require less light energy reduces the stiffness build-up and increases the flow of material during the curing process. This approach avoids stress concentration at the adhesive interface ${ }^{4,9}$. Although many studies have evaluated this phenomenon in composite resin restorations, little has been published regarding other clinical situations, such as those related to pit and fissure sealing.

The elastic modulus of the restorative materials has been reported to be a relevant factor for the generation of shrinkage stress ${ }^{15}$. As the elastic modulus increases, more shrinkage stress is transmitted to the adhesive interface, and more pronounced gap formation occurs ${ }^{15,24}$. Materials with lower elastic modulus can be used as an elastic "stress absorbing" layer. This layer may absorb sufficient strain to counterbalance the stress induced by the polymerization shrinkage when the composite resin is bonded to the cavity walls ${ }^{24}$. Conversely, it is known that the stress generation is related to polymerization shrinkage ${ }^{15,24}$, so similar results for both adhesive systems tested could be expected. However, the detected difference can be related to the lower elastic modulus of OptiBond FL, which may support the stress generated by the load cycling.

Armstrong et al. ${ }^{2}$ (2001) considered that the elastic "stress absorbing" layer concept could be valid in high $\mathrm{C}$-factor cavities. However, similar bond strength values were obtained using two different adhesives (filled and unfilled) in low $\mathrm{C}$-fac- 
Grande RHM, Reis A, Loguercio AD, Singer JM, Shellard E, Christino Neto P. Adhesive systems used for sealing contaminated surfaces: a microleakage evaluation. Braz Oral Res 2005;19(1):17-22.

tor cavities (similar to the "occlusal surface" used in this study). In the present study, this feature seems less significant, since the sealant was placed in an "almost" flat surface, with no cavities on the occlusal surface and uneteched enamel surfaces at the deep portion of fissures ${ }^{6}$. Likewise, conditioning was usually confined to enamel of the inclined cuspal planes, e.g. the total fissure obturation is not a common feature and the unbonded surface could be as great as the bonded surface and thus, the $\mathrm{C}$-factor is very favorable ${ }^{8}$. This allows stress relaxation by flow on the unbonded surface and avoids stress concentration at the adhesive interface.

Actually, this could also be one of the reasons for the similar performance of the adhesive systems under the different light intensities. In low $\mathrm{C}$-factor cavities, the flow ability of polymer-based materials on unbonded surfaces is higher and does not require low light intensity techniques to avoid stress concentration at the adhesive interface ${ }^{9}$.

Leakage tests of the tooth/material interface are among the most frequently used laboratory analyses to investigate the sealing ability of dental materials. In many of these tests, thermal stress has been used to simulate the hot and cold fluctuation present in the oral environment, although it has never been demonstrated that cycling tests are relevant to clinical failures ${ }^{10,21}$. The results of the effects of thermocycling on microleakage are variable, mainly because the corresponding methods, regimens and materials are quite different ${ }^{10,11,16,18,22}$, complicating the comparison of reports.

Mechanical stress seems to significantly change the marginal sealing ${ }^{1,26}$. However, standardization of the number of cycles and the load levels are still lacking ${ }^{10}$. According to Nikaido et al. ${ }^{18}$ (2002), deformation of the restorations can occur due to loading and thermal cycling, which may cause micro-separations between the teeth

\section{REFERENCES}

1. Abdalla AI, Davidson CL. Effect of mechanical load cycling on the marginal integrity of adhesive class I resin composite restorations. J Dent 1996;24:87-90.

2. Armstrong SR, Keller JC, Boyer DB. The influence of water storage and C-factor on the dentin-resin composite microtensile bond strength and debond pathway utilizing a filled and unfilled adhesive resin. Dent Mater 2001;17:268-76.

3. Cueto EI, Buonocore MG. Sealing of pits and fissures with an adhesive resin. Its use in caries prevention. J Am Dent Assoc 1967;75:121-8. and the adhesive or plastic deformations of the adhesive interface.

It must be pointed out that in an oral cavity, besides the aqueous environment, numerous factors like hydrolytic enzyme action, ionic composition of the saliva, $\mathrm{pH}$ fluctuation due to cariogenic microorganisms or acidic food may influence the quality of marginal integrity. Seldom have studies subjected specimens to demineralization-remineralization solutions to mimic aging and clinical conditions. In general, this methodology is used to evaluate the ability of dental materials to assess the caries-inhibitory properties on the enamel interface ${ }^{7,19}$.

As little attention has been given to the effect of $\mathrm{pH}$ cycling on the sealing ability of different materials, this study attempted to verify the influence of $\mathrm{pH}$ associated with other aging treatments on the enamel-sealant margins. Despite the fact that no significant effects of $\mathrm{pH}$ cycling were detected, further studies should be conducted to determine the exact parameters required for $\mathrm{pH}$ cycling to influence leakage and longevity data.

\section{CONCLUSIONS}

The main conclusion drawn from this study is that regarding microleakage, OptiBond FL could be used as a sole material for pit and fissure sealing. An additional conclusion is that neither light activation nor load/thermal/pH cycling are significantly related to the performance of the adhesive systems.

\section{ACKNOWLEDGMENTS}

This study was partially supported by FAPESP (the State of São Paulo Research Foundation) (96/06216-8), CAPES (Coordination for the Improvement of Higher Education Personnel) and CNPq (National Council for Scientific and Technological Development) (300086/01-6).

4. Davidson-Kaban SS, Davidson CL, Feilzer AJ, de Gee AJ, Erdilek N. The effect of curing light variations on bulk curing and wall-to-wall quality of two types and various shades of resin composites. Dent Mater 1997;13:344-52.

5. Dennison JB, Straffon LH, More FG. Evaluation of tooth eruption on sealant efficacy. J Am Dent Assoc 1990;121:610-4.

6. Duangthip D, Lussi A. Microleakage and penetration ability of resin sealant versus bonding system when applied following contamination. Pediatr Dent 2003;25:505-11. 
Grande RHM, Reis A, Loguercio AD, Singer JM, Shellard E, Christino Neto P. Adhesive systems used for sealing contaminated surfaces: a microleakage evaluation. Braz Oral Res 2005;19(1):17-22.

7. Featherstone JD. Modeling the caries-inhibitory effects of dental materials. Dent Mater 1996;12:194-7.

8. Feilzer AJ, De Gee AJ, Davidson CL. Setting stress in composite resin in relation to configuration of the restoration. J Dent Res 1987;66:1636-9.

9. Feilzer AJ, Dooren LH, de Gee AJ, Davidson CL. Influence of light intensity on polymerization shrinkage and integrity of restoration-cavity interface. Eur J Oral Sci 1995;103:322-6.

10. Gale MS, Darvell BW. Thermal cycling procedures for laboratory testing of dental restorations. J Dent 1999;27:89-99.

11. Grande RHM, Ballester RY, Singer JM, Santos JFF. Microleakage of a universal adhesive used as a fissure sealant. Am J Dent 1998;11:109-13.

12. Grande RHM, Lima ACP, Rodrigues Filho LE, Witzel MF. Clinical evaluation of an adhesive used as a fissure sealant. Am J Dent 2000;13:167-70.

13. Hebling JC, Feigal RJ. Use of one-bottle adhesive as an intermediate bonding layer to reduce sealant microleakage on saliva-contaminated enamel. Am J Dent 2000;13:187-91.

14. Jain P, Stewart GP. Effect of dentin primer on shear bond strength of composite resin to moist and dry enamel. Oper Dent 2000;25:51-8.

15. Labella R, Lambrechts P, Van Meerbeek B, Vanherle G. Polymerization shrinkage and elasticity of flowable composites and filled adhesives. Dent Mater 1999;15:128-37.

16. Li H, Burrow MF, Tyas MJ. The effect of thermocycling regimens on the nanoleakage of dentin bonding systems. Dent Mater 2002;18:189-96.

17. Neter J, Kutner MH, Nachtsheim CJ, Wasserman W. Applied linear statistical models. $4^{\text {th }}$ ed. Boston: Richard D. Irwin Inc; 1996.
18. Nikaido T, Kunzelmann KH, Chen H, Ogata M, Harada $\mathrm{N}$, Yamaguchi $\mathrm{S}$, et al. Evaluation of thermal cycling and mechanical loading on bond strength of a self-etching primer system to dentin. Dent Mater 2002;18:269-74.

19. Pimenta LAF, Fontana UF, Cury JA, Serra MC, Elderton RJ. Inhibition of demineralization in vitro around amalgam restorations. Quintessence Int 1998;29:363-7.

20. Pintado MR, Douglas WH. The comparison of microleakage between two different dentin bonding resin systems. Quintessence Int 1988;19:905-7.

21. Rossomando KJ, Wendt SL Jr. Thermocycling and dwell times in microleakage evaluation for bonded restorations. Dent Mater 1995;11:47-51.

22. Symons AL, Chu CY, Meyers IA. The effect of fissure morphology and pretreatment of the enamel surface on penetration and adhesion of fissure sealants. J Oral Rehabil 1996;23:791-8.

23. ten Cate JM, Duijsters PP. Alternating demineralization and remineralization of artificial enamel lesions. Caries Res 1982;16:201-10.

24. Unterbrink GL, Liebenberg WH. Flowable resin composites as "filled adhesives": literature review and clinical recommendations. Quintessence Int 1999;30:249-57.

25. Waggoner W, Siegal M. Pit and fissure sealant application: updating the technique. J Am Dent Assoc 1996;127:351-61.

26. Witzel MF, Grande RHM, Singer JM. Bonding systems used for sealing: evaluation of microleakage. J Clin Dent 2000;11:47-52.

27. Wu W, Cobb EN. A silver staining technique for investigating wear of restorative dental composites. J Biomed Mater Res 1981;15:343-8.

Received for publication on Sep 24, 2004

Sent for alterations on Feb 03, 2005

Accepted for publication on Feb 21, 2005 